Sains Malaysiana 49(4)(2020): 899-908

http://dx.doi.org/10.17576/jsm-2020-4904-19

\title{
Analisis Kestabilan Aliran Genangan bagi Bendalir Mikrokutub terhadap Permukaan Mencancang dengan Fluks Haba Ditetapkan
}

(Stability Analysis of Stagnation Flow of a Micropolar Fluid towards a Vertical Surface with Prescribed Heat Flux)

\author{
FATINNABILA KAMAL, KHAIRY ZAIMI \& ANUAR ISHAK*
}

\section{ABSTRAK}

Tujuan penyelidikan ini adalah untuk mengkaji kestabilan aliran bendalir bagi masalah aliran genangan dalam bendalir mikrokutub terhadap permukaan mencancang yang telap dengan fluks haba ditetapkan. Persamaan menakluk dalam bentuk persamaan pembezaan separa tak linear dijelmakan kepada sistem persamaan pembezaan biasa tak linear menggunakan penjelmaan keserupaan seterusnya diselesaikan secara berangka menggunakan penyelesai masalah nilai sempadan, bvp4c dibina dalam perisian MATLAB. Keputusan berangka diperoleh bagi pekali geseran kulit, nombor Nusselt setempat serta profil halaju dan suhu bagi beberapa nilai parameter menakluk yang terlibat. Penyelesaian dual didapati wujud bagi julat-julat tertentu parameter keapungan atau parameter olakan campuran dalam kedua-dua aliran membantu dan aliran menentang. Analisis kestabilan dilakukan untuk menentukan penyelesaian yang stabil dalam masa panjang. Didapati bahawa hanya satu daripada penyelesaian tersebut yang stabil apabila masa berlalu.

Kata kunci: Analisis kestabilan; aliran genangan; bendalir mikrokutub; penyelesaian dual; sedutan/semburan

\section{ABSTRACT}

The purpose of this study was to investigate the stability of fluid flow for the problem of stagnation flow in a micropolar fluid towards a vertical permeable surface with prescribed heat flux. The governing nonlinear partial differential equations are transformed into a system of nonlinear ordinary differential equations using a similarity transformation which are then solved numerically using the boundary value problem solver, bvp4c built in MATLAB software. The numerical results are obtained for the skin friction coefficient, local Nusselt number as well as the velocity and temperature profiles for some values of the governing parameters involved. Dual solutions are found to exist for a certain range of the bouyancy parameter or the mixed convection parameter in both assisting and opposing flows. A stability analysis is performed to determine which solution is stable in a long run. It is found that only one of the solutions is stable as time passes.

Keywords: Dual solutions; micropolar fluid; stability analysis; stagnation flow; suction/injection

\section{INTRODUCTION}

Kajian berkaitan bendalir mikrokutub telah menjadi salah satu tumpuan penyelidik kebelakangan ini kerana ia mempunyai pelbagai aplikasi dalam bidang kejuruteraan. Banyak proses kejuruteraan melibatkan bendalir tak Newtonan seperti cat, pelincir, darah manusia dan haiwan dan polimer. Namun begitu, teori klasik bendalir Newtonan tidak boleh digunakan untuk menerangkan telatah bendalir tak Newtonian ini (Gupta et al. 2018). Eringen (1966) telah memperkenalkan teori bendalir mikrokutub, yang menerangkan keadaan fizik bendalir tersebut dengan mengambil kira kesan yang terhasil daripada struktur setempat dan pergerakan mikro unsur-unsur bendalir. Teori ini mempertimbangkan satu lagi persamaan, iaitu persamaan yang memenuhi prinsip keabadian momentum sudut, selain daripada persamaan keselanjaran dan persamaan momentum yang biasa ditemui dalam teori klasik bendalir Newtonan. Bendalir mikrokutub ini boleh menyokong tekanan gandingan, tegasan ricih dan juga mempamerkan kesan putaran mikro dan inersia (Gupta et al. 2018). Eringen (2001) dalam bukunya turut menjelaskan asas-asas teori bendalir mikrokutub beserta dengan beberapa aplikasi kejuruteraan mudah. Antara kajian awal bendalir mikrokutub termasuk kajian yang dilakukan oleh Asgharian et al. (2010), Hassanien dan Gorla (1990), Ishak (2010), Mohamed dan Abo-Dahab (2009), Yacob dan Ishak (2010) dan Zaimi dan Ishak (2012).

Sejak akhir-akhir ini, penyelidik mula mempertimbangkan analisis kestabilan bagi pelbagai masalah aliran dan pemindahan haba dan menganalisis keputusan kajian yang mempunyai penyelesaian dual untuk menentukan penyelesaian stabil dan relevan secara fizikal. Antara kajian tersebut termasuklah kajian oleh Awaludin et al. (2018), Bakar et al. (2018), Ishak et al. (2010), Jahan et al. (2018), Jamaluddin et al. (2018, 2017), Jusoh et al. (2018), Kamal et al. (2019), Merkin (1986), Weidman et al. (2006) dan Yahaya et al. (2019). 
Dalam kajian ini, telatah aliran genangan dan pemindahan haba dalam bendalir mikrokutub terhadap permukaan mencancang yang telap dengan kesan sedutan dan semburan diselesaikan secara berangka. Kajian ini adalah perluasan kajian yang dilakukan oleh Asgharian et al. (2010) yang menyelesaikan masalah aliran genangan bendalir mikrokutub terhadap permukaan mencancang yang telap bagi kedua-dua aliran membantu dan aliran menentang menggunakan kaedah analitik iaitu, kaedah analisis homotopi (HAM). Namun begitu, Asgharian et al. (2010) tidak melaporkan kewujudan penyelesaian dual. Kajian ini berbeza dengan Asgharian et al. (2010) daripada segi keadaan pemanasan permukaan. Asgharian et al. (2010) mempertimbangkan kes suhu permukaan ditetapkan, manakala kajian ini mempertimbangkan kes fluks haba permukaan ditetapkan, juga melaporkan kewujudan penyelesaian dual. Selain itu, analisis kestabilan dilakukan untuk menentukan penyelesaian yang stabil dan mempunyai implikasi fizikal yang sebenar. Kesan parameter sedutan/semburan pada pekali geseran kulit, nombor Nusselt setempat serta profil-profil halaju dan suhu dianalisis dan dibincangkan.

\section{FORMULASI MATEMATIK}

Pertimbangkan aliran genangan dua matra normal terhadap plat tegak dalam bendalir mikrokutub tak mampat seperti ditunjukkan dalam Rajah 1. Berdasarkan Rajah 1, plat tertakluk kepada fluks haba boleh ubah $q_{w}$ (x). Diandaikan wujud aliran bebas $U(\mathrm{x})$ yang mengalir di sepanjang plat dan daya keapungan boleh bertindak dalam aliran membantu atau aliran menentang dengan aliran bebas. Diandaikan bahawa $U(\mathrm{x})=\alpha x$ dan $q_{w}(x)$ $=b x$, yang $\alpha$ dan $\mathrm{b}$ adalah pemalar. Dengan andaian ini beserta dengan penghampiran Boussinesq, persamaan menakluk dapat ditulis sebagai (Asgharian et al. (2010)):

$$
\begin{gathered}
\frac{\partial u}{\partial x}+\frac{\partial v}{\partial y}=0 \\
u \frac{\partial u}{\partial x}+v \frac{\partial u}{\partial y}=U \frac{d U}{d x}+\frac{\mu+\kappa}{\rho} \frac{\partial^{2} u}{\partial y^{2}}+\frac{\kappa}{\rho} \frac{\partial N}{\partial y}+g \beta\left(T-T_{w}\right) \\
u \frac{\partial N}{\partial x}+v \frac{\partial N}{\partial y}=\frac{\gamma}{\rho j} \frac{\partial^{2} N}{\partial y^{2}}-\frac{\kappa}{\rho j}\left(2 N+\frac{\partial u}{\partial y}\right) \\
u \frac{\partial T}{\partial x}+v \frac{\partial T}{\partial y}=\alpha \frac{\partial^{2} T}{\partial y^{2}}
\end{gathered}
$$

Diandaikan bahawa (1) - (4) tertakluk kepada syarat sempadan:

$$
u=0, v=V_{w}, N=-m \frac{\partial u}{\partial y}, k \frac{\partial T}{\partial y}=-q_{w}(x), \quad \text { pada } \mathrm{y}=0,
$$

$u \rightarrow U(x), N \rightarrow 0, T \rightarrow T_{\infty}$, apabila $\mathrm{y} \rightarrow \infty$

dengan $u$ dan $v$ masing-masing adalah komponen halaju sepanjang paksi $x$ dan $y, T$ dan $T_{\infty}$ masing-masing adalah suhu bendalir dan suhu persekitaran, $N$ adalah mikroputaran $p$, adalah ketumpatan bendalir, $\mu$ adalah kelikatan dinamik, $k$ adalah kelikatan vorteks, $g$ adalah pecutan graviti, $\gamma$ adalah kelikatan kecerunan putaran, $\alpha$ adalah pekali resapan terma, $\beta$ adalah pekali kembangan terma, $j$ adalah mikroinersia, dan $V$ adalah fluks jisim permukaan seragam, yang $V_{w}>0$ mewakili semburan, manakala $V_{w}<0$ mewakili sedutan pada permukaan. Dalam kajian ini, $m$ adalah parameter sempadan dengan $0 \leq m \leq 1$ (Nazar et al. 2004) manakala sebutan terakhir pada sebelah kanan (2) adalah merujuk kepada pengaruh daya keapungan terma dalam medan aliran. Kesan mikrostruktur mungkin tidak ketara dan jumlah putaran $N$ menjadi halaju sudut dalam sesetengah kes. Seperti dilaporkan oleh Ahmadi (1976), Gorla (1988) dan Kline (1977), kelikatan kecerunan putaran $\gamma$ diberi oleh $\gamma=(\mu$ $+\kappa / 2) j=\mu(1+K / 2) j$, dengan $K=k / \mu$ adalah parameter bahan.

Untuk mendapatkan penyelesaian keserupaan bagi persamaan menakluk (1)-(4) tertakluk kepada syaratsyarat sempadan (5), penjelmaan keserupaan berikut diperkenalkan:

$$
\begin{gathered}
\eta=(U / v x)^{1 / 2} y, \psi=(U v x)^{1 / 2} f(\eta), \\
\theta(\eta)=\frac{k\left(T-T_{\infty}\right)}{q_{w}}\left(\frac{U}{v x}\right)^{1 / 2}, \phi(\eta)=N\left(\frac{v x}{U^{3}}\right),
\end{gathered}
$$

dengan $\eta$ adalah pemboleh ubah keserupaan, $f(\eta), \phi(\eta)$ $\theta(\eta)$ masing-masing adalah fungsi strim, mikroputaran dan suhu tanpa matra. Sementara itu, $v$ adalah kelikatan kinematik dan $\psi$ adalah fungsi strim yang ditakrifkan sebagai $u=\partial \psi / \partial y$ dan $v=-\partial \psi / \partial x$ dengan persamaan keselanjaran (1) dipenuhi.

Dengan menggantikan (6) ke dalam (2)-(4), persamaan perbezaan biasa tak linear berikut diperoleh

$$
\begin{gathered}
(1+K) f^{\prime \prime \prime}+f f^{\prime \prime}+1-f^{2}+K \phi^{\prime}+\lambda \theta=0 \\
\left(1+\frac{K}{2}\right) \phi^{\prime \prime}+f \phi^{\prime}-f^{\prime} \phi-K\left(2 \phi+f^{\prime \prime}\right)=0 \\
\frac{1}{\operatorname{Pr}} \theta^{\prime \prime}+f \theta^{\prime}-f^{\prime} \theta=0
\end{gathered}
$$

Menggunakan (6), syarat-syarat sempadan (5) terturun kepada

$$
\begin{gathered}
f(0)=S, f^{\prime}(0)=0, \phi(0)=-m f^{\prime \prime}(0), \theta^{\prime}(0)=-1 \\
f^{\prime}(\eta) \rightarrow 1, \phi(\eta) \rightarrow 0, \quad \theta(\eta) \rightarrow 0, \text { apabila } \eta \rightarrow \infty
\end{gathered}
$$


dengan tanda (') merujuk kepada pembezaan terhadap $\eta$, $\operatorname{Pr}=v / \alpha$ adalah nombor Prandtl, manakala $\lambda=\mathrm{Gr}_{x} /$ $\operatorname{Re}^{2}{ }_{x}$ merupakan parameter keapungan atau paramaeter olakan campuran dengan $\mathrm{Gr}_{x}=g \beta\left(T_{w}-T_{\infty}\right) x^{3} / v^{2}$ adalah nombor Grashof setempat dan $\operatorname{Re}_{x}=U x / v$ adalah nombor Reynolds setempat. Dalam (10), $S=-V_{w} / \sqrt{v a}$ mewakili perameter sedutan/semburan dengan $S<0$ mewakili semburan, $S>0$ mewakili sedutan, manakala $S=0$ mewakili ke plat tak telap.

Kuantiti fizikal yang dikaji dalam kajian ini adalah pekali geseran kulit $C_{f}$ dan nombor Nusselt setempat $N u_{x}$ yang diberi oleh

$$
C_{f}=\frac{\tau_{w}}{\rho U^{2} / 2}, N u_{x}=\frac{x q_{w}}{k\left(T_{w}-T_{\infty}\right)}
$$

dengan $\tau_{w}$ adalah tegasan ricih permukaan dan $q_{w}$ adalah fluks haba permukaan yang ditakrifkan sebagai

$$
\tau_{w}=\left((\mu+\kappa) \frac{\partial u}{\partial y}+\kappa N\right)_{y=0}, q_{w}=-k\left(\frac{\partial T}{\partial y}\right)_{y=0} .
$$

Dengan menggantikan (6) dan (11) ke dalam (12) diperoleh

$$
\frac{1}{2} C_{f} \operatorname{Re}_{x}^{1 / 2}=[1+(1-m) K] f^{\prime \prime}(0), \mathrm{Nu}_{x} \operatorname{Re}_{x}^{-1 / 2}=\frac{1}{\theta(0)} .
$$

\section{ANALISIS KESTABILAN}

Analisis kestabilan adalah satu daripada pendekatan yang digunakan untuk menentukan penyelesaian manakah yang stabil dalam masa panjang daripada penyelesaian dual yang diperoleh. Dalam kajian ini, analisis kestabilan dilakukan seperti mana dilakukan oleh Merkin (1986), Weidman et al. (2006), dan Rosca dan Pop (2013). Menurut Weidman et al. (2006), satu pemboleh ubah masa tanpa matra perlu diperkenalkan. Maka, masalah yang tak mantap perlu dipertimbangkan bagi membolehkan analisis kestabilan dilakukan. Bentuk tak mantap bagi persamaan menakluk (2) - (4) adalah

$$
\begin{gathered}
\frac{\partial u}{\partial t}+u \frac{\partial u}{\partial x}+v \frac{\partial u}{\partial y}=U \frac{d U}{d x}+\frac{\mu+\kappa}{\rho} \frac{\partial^{2} u}{\partial y^{2}}+\frac{\kappa}{\rho} \frac{\partial N}{\partial y}+g \beta\left(T-T_{w}\right) \\
\frac{\partial N}{\partial t}+u \frac{\partial N}{\partial x}+v \frac{\partial N}{\partial y}=\frac{\gamma}{\rho j} \frac{\partial^{2} N}{\partial y^{2}}-\frac{\kappa}{\rho j}\left(2 N+\frac{\partial u}{\partial y}\right) \\
\frac{\partial T}{\partial t}+u \frac{\partial T}{\partial x}+v \frac{\partial T}{\partial y}=\alpha \frac{\partial^{2} T}{\partial y^{2}}
\end{gathered}
$$

dengan persamaan keselanjaran (1) adalah kekal sama dan $t$ merujuk kepada masa. Penjelmaan keserupaan baru bagi masalah tak mantap diperkenalkan seperti berikut:

$$
\eta=\left(\frac{U}{v x}\right)^{\frac{1}{2}} y, u=a x f^{\prime}(\eta, \tau), v=-(v a)^{\frac{1}{2}} f(\eta, \tau),
$$

$\phi(\eta, \tau)=N \sqrt{\frac{v x}{U^{3}}}, \theta(\eta, \tau)=\frac{k\left(T-T_{\infty}\right)}{q_{w}}\left(\frac{U}{v x}\right)^{\frac{1}{2}}, \tau=a t$.

Dengan menggantikan (17) ke dalam (14)-(16), diperoleh

$$
\begin{gathered}
(1+K) \frac{\partial^{3} f}{\partial \eta^{3}}+f \frac{\partial^{2} f}{\partial \eta^{2}}+1-\left(\frac{\partial f}{\partial \eta}\right)^{2}+K \frac{\partial \phi}{\partial \eta}+\lambda \theta-\frac{\partial^{2} F}{\partial \eta \partial \tau}=0 \\
\left(1+\frac{K}{2}\right) \frac{\partial^{2} \phi}{\partial \eta^{2}}-\frac{\partial f}{\partial \eta} \phi+f \frac{\partial \phi}{\partial \eta}-K\left(2 \phi+\frac{\partial^{2} f}{\partial \eta^{2}}\right)-\frac{\partial \phi}{\partial \tau}=0 \\
\frac{1}{\operatorname{Pr}} \frac{\partial^{2} \theta}{\partial \eta^{2}}+f \frac{\partial \theta}{\partial \eta}-\frac{\partial f}{\partial \eta} \theta-\frac{\partial H}{\partial \tau}=0
\end{gathered}
$$

tertakluk kepada syarat sempadan:

$$
\begin{gathered}
f(0, \tau)=S, \frac{\partial f}{\partial \eta}(0, \tau)=0, \phi(0, \tau)=-m \frac{\partial^{2} f}{\partial \eta^{2}}(0, \tau), \frac{\partial \theta}{\partial \eta}(0, \tau)=-1, \\
\frac{\partial f}{\partial \eta}(\eta, \tau)=1, \phi(\eta, \tau)=0, \theta(\eta, \tau)=0, \text { as } \eta \rightarrow \infty .
\end{gathered}
$$

Merujuk kepada Awaludin et al. (2018), Rosca dan Pop (2013), dan Weidman et al. (2006) untuk menentukan kestabilan bagi aliran mantap $f=f_{0}(\eta), \phi=\phi_{0}(\eta)$ dan $\theta$ $(\eta)=\theta_{0}(\eta)$ yang memenuhi (7)-(9) tertakluk kepada syarat sempadan (10), pertimbangkan usikan dalam bentuk eksponen

$$
\begin{gathered}
f(\eta, \tau)=f_{0}(\eta)+e^{-\varepsilon \tau} F(\eta), \\
\phi(\eta, \tau)=\phi_{0}(\eta)+e^{-\varepsilon \tau} G(\eta), \\
\theta(\eta, \tau)=\theta_{0}(\eta)+e^{-\varepsilon \tau} H(\eta),
\end{gathered}
$$

dengan $\mathcal{E}$ adalah nilai eigen yang tidak diketahui dan $F(\eta), G(\eta)$ dan $H(\eta)$ adalah relatif kecil terhadap $f_{0}$ $(\eta), \phi_{0}(\eta)$ dan $\theta_{0}(\eta)$. Penyelesaian bagi masalah nilai eigen (18)-(21) memberikan set nilai eigen tak terhingga $\boldsymbol{\varepsilon}<\boldsymbol{\varepsilon}_{2}<\boldsymbol{\varepsilon}_{3} \ldots$,jika $\boldsymbol{\varepsilon}_{1}$ adalah negatif terdapat pertumbuhan awal dan aliran adalah tak stabil tetapi apabila $\varepsilon_{1}$ adalah positif, terdapat penyusutan awal, aliran tak mantap $f(\eta$, $\tau), \phi(\eta, \tau), \theta(\eta, \tau)$ menumpu kepada aliran mantap $f_{0}(\eta)$, $\phi_{0}(\eta), \theta_{0}(\eta)$, dan aliran adalah stabil apabila masa berlalu.

Setelah (22) digantikan ke dalam (18)-(20), selepas pelinearan, diperoleh:

$$
\begin{gathered}
(1+K) F^{\prime \prime \prime}+f_{0} F^{\prime \prime}+f^{\prime \prime}{ }_{0} F-\left(2 f_{0}^{\prime}-\varepsilon\right) F^{\prime}+K G^{\prime}+\lambda H=0, \\
\left(1+\frac{K}{2}\right) G^{\prime \prime}-f_{0}^{\prime} G-\phi_{0} F^{\prime}+f_{0} G^{\prime}+\phi_{0}^{\prime} F-(2 K-\varepsilon) G-K F^{\prime \prime}=0, \\
\frac{1}{\operatorname{Pr}} H^{\prime \prime}+f_{0} H^{\prime}+\theta_{0}^{\prime} F-\left(f_{0}^{\prime}-\varepsilon\right) G-F^{\prime} \theta_{0}=0,
\end{gathered}
$$

dengan syarat sempadan

$$
\begin{gathered}
F(\eta)=0, G(\eta)=-m F^{\prime \prime}(\eta), H^{\prime}(\eta)=0, \text { pada } \eta=0, \\
F^{\prime}(\eta) \rightarrow 0, G(\eta) \rightarrow 0, H(\eta) \rightarrow 0 \text { apabila } \eta \rightarrow \infty .
\end{gathered}
$$




\section{HASIL DAN PERBINCANGAN}

Persamaan pembezaan biasa tak linear (7)-(9) tertakluk kepada syarat sempadan (10) diselesaikan secara berangka menggunakan penyelesai masalah nilai sempadan, bvp4c dibina dalam perisian MATLAB. Keputusan berangka diperoleh untuk menggambarkan kesan beberapa parameter menakluk terhadap pekali geseran kulit $\frac{1}{2} C_{f}$ $\operatorname{Re}_{\mathrm{x}}{ }^{1 / 2}$ nombor Nusselt setempat $\mathrm{Nu}_{\mathrm{x}} \operatorname{Re}_{\mathrm{x}}{ }^{-1 / 2}$ (mewakili kadar pemindahan haba pada permukaan) serta profil halaju $f^{\prime}(\eta)$ dan profil suhu $\theta(\eta)$. Kesan parameter sedutan/ semburan $S$ pada ciri aliran dan pemindahan haba dikaji dan dibincangkan. Bagi menentusah keputusan berangka yang diperoleh, kami telah membandingkan dengan keputusan berangka yang dilaporkan oleh Ramachandran et al. (1988) bagi kes aliran bendalir likat iaitu persamaan momentum sudut (3) diabaikan dan tiada kesan sedutan/ semburan dipertimbangkan. Keputusan perbandingan menunjukkan keputusan berangka yang diperoleh adalah baik seperti ditunjukkan dalam Jadual 1 and 2 sekaligus memberi keyakinan terhadap keputusan berangka lain yang akan dilaporkan berikutnya.

Jadual 3 memaparkan nilai-nilai pekali geseran kulit $\frac{1}{2} C_{f} \operatorname{Re}_{x}^{1 / 2}$ dan nombor Nusselt setempat bagi beberapa nilai $\lambda$ dan $S$ apabila $\operatorname{Pr}$ dan $K$ ditetapkan. Dapat diperhatikan bahawa nilai-nilai pekali geseran kulit $\frac{1}{2} C_{f}$ $\operatorname{Re}_{\mathrm{x}}^{1 / 2}$ dan nombor Nusselt setempat $\mathrm{Nu}_{\mathrm{x}} \operatorname{Re}_{\mathrm{x}}^{-1 / 2}$ meningkat dengan peningkatan nilai $\lambda$. Jadual 3 juga menyokong kewujudan penyelesaian dual bagi kedua-dua aliran membantu dan aliran menentang dengan penyelesaian kedua diberikan dalam kurungan ( ).

Rajah 2-4 memaparkan perubahan pekali geseran kulit $\frac{1}{2} C_{f} \operatorname{Re}_{x}^{1 / 2}$, perubahan nombor Nusselt setempat $\mathrm{Nu}_{\mathrm{x}}$ $\operatorname{Re}_{\mathrm{x}}{ }^{-1 / 2}$ dan perubahan suhu bendalir pada permukaan $\theta(0)$ terhadap parameter keapungan atau parameter olakan campuran $\lambda$ bagi beberapa nilai parameter sedutan/semburan $S$. Berdasarkan Rajah 2-4, didapati wujud penyelesaian dual bagi (7) - (9) tertakluk kepada syarat sempadan (10). Penyelesaian berangka wujud dalam tiga julat parameter keapungan $\lambda$ seperti yang digambarkan dalam Rajah 2-4. Terdapat nilai kritikal parameter keapungan $\lambda$ yang ditanda $\lambda_{c}$ dalam aliran menentang dengan penyelesaian dual wujud apabila $\lambda>$ $\lambda_{c}$, penyelesaian unik diperoleh apabila $\lambda=\lambda_{c}$ dan tiada penyelesaian yang diperoleh apabila $\lambda<\lambda_{c}$. Berdasarkan pengiraan berangka, nilai kritikal $\lambda_{c}$ yang diperoleh masing-masing adalah $\lambda_{c}=-1.0342,-1.2424$ dan -2.9890 bagi $S=-0.1,0$ dan 0.5 seperti yang ditunjukkan dalam Rajah 2-4. Dapat diperhatikan bahawa penyelesaian dual wujud bagi aliran membantu $(\lambda>0)$ manakala penyelesaian dual wujud sehingga nilai kritikal $\lambda_{c}$ bagi aliran menentang $(\lambda<0)$.

Dalam perbincangan seterusnya, penyelesaian pertama dan kedua dikategorikan berdasarkan paparan dalam Rajah 2, iaitu penyelesaian pertama mempunyai nilai $\frac{1}{2} \operatorname{Re}_{x}^{1 / 2} C_{f}$ yang lebih tinggi berbanding penyelesaian kedua bagi suatu nilai $\lambda$ yang ditetapkan. Berdasarkan Rajah 2 dan 3 serta Jadual 3, dapat diperhatikan bahawa kedua-dua nilai pekali geseran kulit dan nombor Nusselt setempat meningkat bagi aliran membantu $(\lambda>0)$ manakala telatah sebaliknya ditunjukkan bagi aliran menentang $(\lambda<0)$. Secara fizikal, fenomenon ini terjadi kerana wujud kecerunan tekanan dalam aliran membantu yang dihasilkan oleh daya keapungan seterusnya mempercepatkan aliran sekaligus meningkatkan pekali geseran kulit dan kadar pemindahan haba pada permukaan. Rajah 2 dan 3 juga memaparkan bahawa nilai-nilai kritikal parameter keapungan $\lambda_{c}$ yang penyelesaiannya wujud, meningkat dengan peningkatan parameter sedutan/ semburan $S$, menunjukkan bahawa parameter $S$ berperanan dalam meluaskan julat penyelesaian dual bagi persamaan (7) - (10)

Rajah 3 memaparkan perubahan suhu permukaan $\theta$ (0) terhadap parameter keapungan $\lambda$. Dapat diperhatikan bahawa suhu permukaan berkurang dalam aliran membantu pada penyelesaian pertama seperti ditunjukkan dalam Rajah 3. Bagi penyelesaian kedua, suhu bendalir pada permukaan juga meningkat dan menyusut menjadi tanpa had apabila $\lambda \rightarrow 0^{+}$dan $\lambda \rightarrow 0^{-}$menunjukkan dengan jelas nilai $\theta(0)$ tidak wujud apabila $\lambda=0$. Ini menjelaskan lagi bahawa penyelesaian kedua tidak realistik. Maka, penyelesaian kedua seperti yang dipaparkan dalam Rajah 2 dan 3 juga disifatkan tidak realistik dan tidak membawa maksud fizikal kerana (7) dan (8) saling bergandingan.

Rajah 5 dan 6 masing-masing diplot untuk menunjukkan kesan parameter sedutan/semburan $S$ terhadap $f^{\prime}(\eta)$ yang mewakili profil halaju bagi aliran menentang $(\lambda=-0.8)$ dan aliran membantu $(\lambda=1.5)$. Seperti ditunjukkan dalam Rajah 5, profil halaju bagi aliran menentang menunjukkan kecerunan positif pada permukaan, manakala telatah bertentangan dipaparkan bagi penyelesaian kedua. Bagi aliran membantu, profil halaju bagi kedua-dua penyelesaian menunjukkan kecerunan positif pada permukaan (Rajah 6). Pemerhatian ini konsisten dengan keputusan yang ditunjukkan dalam Rajah 2. Berdasarkan Rajah 5 dan 6 juga dapat dilihat bahawa penyelesaian kedua bagi kedua-dua aliran membantu dan aliran menentang menunjukkan nilai $f^{\prime}<0(\eta)<0$, iaitu kewujudan aliran ke belakang sekaligus mencadangkan bahawa penyelesaian kedua ini tidak stabil dan tidak realistik secara fizikal yang konsisten dengan perbincangan sebelum ini.

Rajah 7 dan 8 diplot untuk menunjukkan kesan parameter $S$ terhadap profil suhu $\theta(\eta)<0$ bagi aliran menentang $(\lambda=-0.8)$ dan aliran membantu $(\lambda=1.5)$. Dapat diperhatikan bahawa suhu bendalir dalam lapisan sempadan menunjukkan nilai positif $\theta(\eta)>0$, bagi kedua-dua penyelesaian pertama dan kedua bagi aliran menentang. Bagi aliran membantu, profil suhu negatif $\theta(\eta)<0$ untuk julat terhingga $\eta$ diperoleh bagi penyelesaian kedua seperti dalam Rajah 8. Oleh itu, dapat disimpulkan 
bahawa penyelesaian kedua seperti yang dipaparkan dalam Rajah 7 dan 8 juga disifatkan tidak stabil dan realistik seperti dibincangkan oleh Ridha (1996) yang menyatakan penyelesaian $\theta(\eta)<0$ adalah tidak relevan secara fizikal.

Seperti yang telah dibincangkan sebelum ini, penyelesaian dual wujud untuk julat tertentu parameter keapungan atau parameter olakan campuran. Oleh itu, analisis kestabilan dilakukan untuk menentukan penyelesaian yang stabil dan wujud secara fizikal. Analisis kestabilan dilakukan dengan menyelesaikan masalah nilai eigen (23-25) tertakluk kepada syarat sempadan (26). Penyelesaian stabil dikenal pasti berdasarkan nilai eigen positif terkecil $\mathcal{E}$ dalam $f(\eta, \tau)=f_{0}(\eta)+e^{-\varepsilon \tau} F(\eta), \phi(\eta, \tau)$ $=\phi_{0}(\eta)+e^{-\varepsilon \tau} G(\eta) \operatorname{dan} \theta(\eta, \tau)=\theta_{0}(\eta)+e^{-\varepsilon \tau} H(\eta)$ yang diberikan dalam (22), manakala penyelesaian tidak stabil dikenal pasti berdasarkan nilai eigen negatif terkecil $\boldsymbol{\varepsilon}$. Apabila $\tau \rightarrow \infty$, nilai-nilai positif $\varepsilon$ memberikan penyusutan awal yang mengakibatkan aliran stabil, manakala nilai-nilai negatif $\varepsilon$ menunjukkan pertumbuhan awal seterusnya menyebabkan aliran tidak stabil. Jadual 4 menunjukkan nilai-nilai eigen terkecil $\varepsilon$ bagi beberapa nilai $S$ dan $\lambda$. Berdasarkan Rajah 2, keputusan berangka memaparkan kesemua penyelesaian pertama mempunyai nilai eigen terkecil $\varepsilon$ yang positif, sebaliknya kesemua penyelesaian kedua mempunyai nilai eigen terkecil $\varepsilon$ yang negatif. Oleh itu, dapat dijelaskan bahawa penyelesaian pertama adalah stabil manakala penyelesaian kedua adalah tak stabil, dalam masa panjang.

Profil halaju dan suhu yang dipaparkan dalam Rajah 5 - 8 didapati memenuhi syarat sempadan jauh daripada permukaan (10) secara asimptot. Ini menyokong kesahan keputusan berangka dan kewujudan penyelesaian dual yang diperoleh dalam Rajah 2-4 serta Jadual 3.

JADUAL 1. Perbandingan nilai-nilai $f$ " (0) dengan Ramachandran et al. (1988) bagi beberapa nilai $\operatorname{Pr}$ apabila $\lambda=1, S=0$ dan $K=0$

\begin{tabular}{|c|c|c|}
\hline $\operatorname{Pr}$ & Ramachandran et al. (1988) & Kajian ini \\
\hline 0.7 & 1.8339 & 1.833876 \\
\hline 1 & - & 1.733838 \\
\hline 5 & - & 1.440536 \\
\hline 7 & 1.4037 & 1.403649 \\
\hline 9 & - & 1.380103 \\
\hline 10 & - & 1.371148 \\
\hline 12 & - & 1.356829 \\
\hline 20 & 1.3237 & 1.323704 \\
\hline 30 & - & 1.303529 \\
\hline 40 & 1.2919 & 1.291872 \\
\hline 50 & - & 1.284115 \\
\hline 60 & 1.2785 & 1.278511 \\
\hline 70 & - & 1.274235 \\
\hline 80 & 1.2708 & 1.270844 \\
\hline 90 & - & 1.268076 \\
\hline 100 & 1.2658 & 1.265765 \\
\hline
\end{tabular}


JADUAL 2. Perbandingan nilai-nilai $1 / \theta(0)$ dengan Ramachandran et al. (1988) bagi beberapa nilai $\operatorname{Pr}$ apabila $\lambda=1, S=0$ dan $K=0$

\begin{tabular}{ccc}
\hline Pr & Ramachandran et al. (1988) & Kajian ini \\
\hline 0.7 & 0.7776 & 0.777608 \\
1 & - & 0.878041 \\
5 & - & 1.510374 \\
7 & 1.6912 & 1.691203 \\
9 & - & 1.840296 \\
10 & - & 1.906663 \\
12 & - & 2.027237 \\
20 & 2.4074 & 2.407431 \\
30 & - & 2.759540 \\
40 & 3.0402 & 3.040241 \\
50 & - & 3.277504 \\
60 & 3.4850 & 3.485040 \\
70 & - & 3.670721 \\
80 & 3.8395 & 3.839531 \\
100 & - & 3.994852 \\
\hline 0 & & \\
\hline
\end{tabular}

JADUAL 3. Nilai-nilai $\frac{1}{2} C_{f} \operatorname{Re}_{x}^{1 / 2}$ dan $\mathrm{Nu}_{x} \operatorname{Re}_{x}^{-1 / 2}$ bagi beberapa nilai $\lambda$ apabila $\operatorname{Pr}=1, K=1$, dan $\mathrm{S}=-0.1,0,0.5$

\begin{tabular}{cccc}
\hline$\lambda$ & $S$ & $\frac{1}{2} C_{f} \mathrm{Re}_{x}^{1 / 2}$ & $\mathrm{Nu}_{x} \mathrm{Re}_{x}^{-1 / 2}$ \\
\hline-1 & -0.1 & $0.330756(-0.095351)$ & $0.540019(0.43911)$ \\
& 0 & $0.657201(-0.440239)$ & $0.654252(0.386351)$ \\
& 0.5 & $1.378925(-1.308110)$ & $1.057545(0.317855)$ \\
-0.8 & -0.1 & $0.712535(-0.386312)$ & $0.608175(0.335193)$ \\
& 0 & $0.884878(-0.576179)$ & $0.689014(0.315079)$ \\
& 0.5 & $1.472343(-1.311154)$ & $1.067346(0.268189)$ \\
& -0.1 & $1.047109(-0.567471)$ & $0.658235(0.220547)$ \\
& 0 & $1.152577(-0.685663)$ & $0.725978(0.212876)$ \\
& 0.5 & $1.606066(-1.291427)$ & $1.080993(0.184851)$ \\
& -0.1 & $2.061930(1.232654)$ & $0.778639(0.979344)$ \\
& 0 & $2.072813(1.080579)$ & $0.831369(1.164981)$ \\
& 0.5 & $2.193705(-0.543383)$ & $1.136380(-1.736579)$ \\
& -0.1 & $2.316755(1.571246)$ & $0.803986(0.877326)$ \\
& & &
\end{tabular}




\begin{tabular}{cccc}
\hline 1.5 & 0 & $2.313288(1.429271)$ & $0.854987(0.976627)$ \\
& 0.5 & $2.368334(0.230791)$ & $1.151607(3.365500)$ \\
& -0.1 & $2.551187(1.858070)$ & $0.826061(0.854572)$ \\
& 0 & $2.536039(1.717811)$ & $0.875780(0.929845)$ \\
& 0.5 & $2.535229(0.683129)$ & $1.165706(1.801755)$ \\
\hline
\end{tabular}

( ) penyelesaian kedua

JADUAL 4. Nilai eigen terkecil, $\varepsilon_{1}$ bagi beberapa nilai $\lambda$ apabila $S=-0.1$, dan $\operatorname{Pr}=K=1$

\begin{tabular}{ccc}
\hline$\lambda$ & Penyelesaian pertama (Cabang atas), & Penyelesaian kedua (Cabang bawah), \\
& $\varepsilon_{1}$ & -0.0009 \\
-1.0342 & 0 & -0.0134 \\
-1.034 & 0.0143 & -0.0462 \\
-1.032 & 0.0461 & -0.0639 \\
-1.03 & 0.0638 & -0.1831 \\
-1.0 & 0.1822 & -0.6531 \\
1.0 & 1.4210 & -0.8058 \\
2.0 & 1.7520 & -0.9379 \\
3.0 & 2.0416 & \\
\hline
\end{tabular}
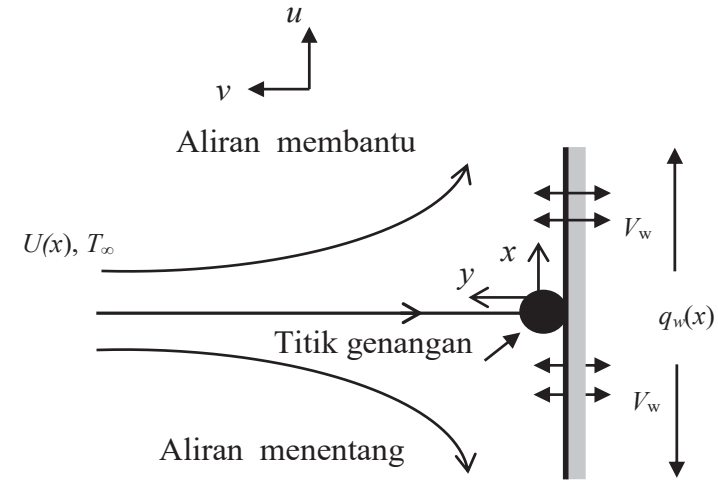

RAJAH 1. Model fizikal

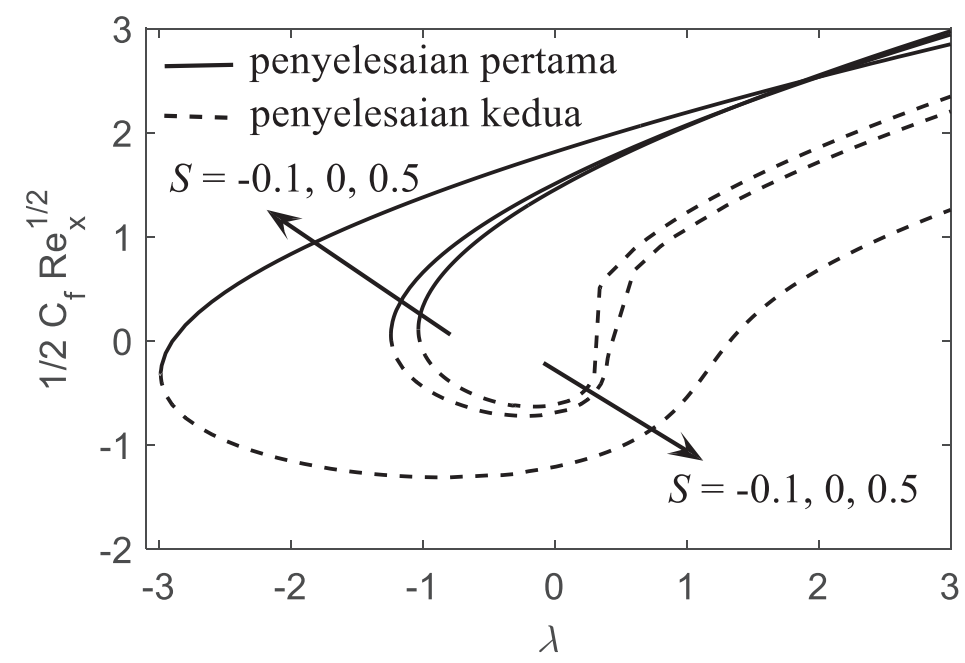

RAJAH 2. Perubahan pekali geseran kulit $\frac{1}{2} C_{f} \operatorname{Re}_{x}^{1 / 2}$ terhadap $\lambda$ bagi beberapa nilai $S$ apabila $\operatorname{Pr}=1$ dan $K=1$ 


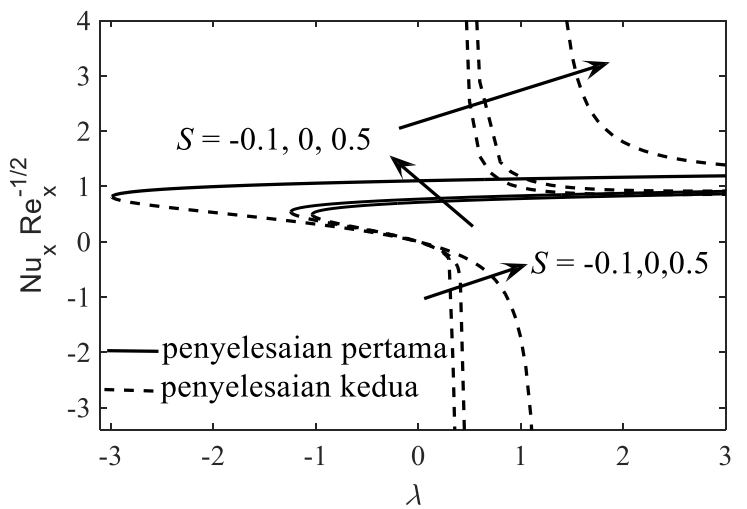

RAJAH 3. Perubahan kadar pemindahan haba pada permukaan $\mathrm{Nu}_{x} \mathrm{Re}_{x}^{-1 / 2}$ terhadap $\lambda$ bagi beberapa nilai $S$ apabila $\operatorname{Pr}=1$ dan $K=1$

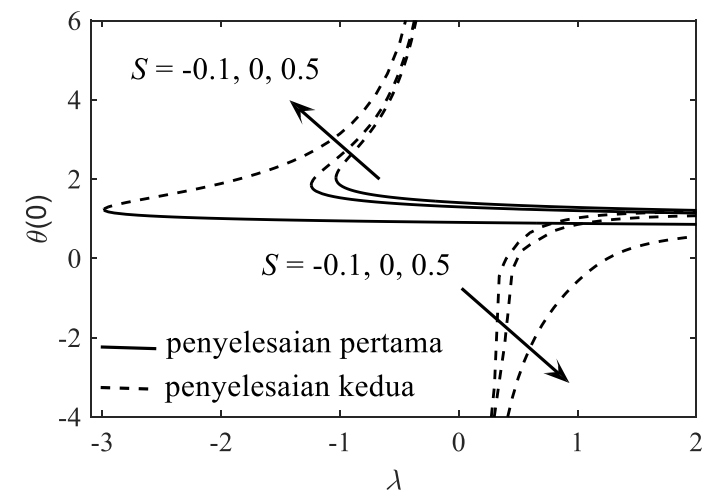

RAJAH 4. Perubahan suhu permukaan $\theta(0)$ terhadap $\lambda$ bagi beberapa nilai $S$ apabila $\operatorname{Pr}=1$ dan $K=1$

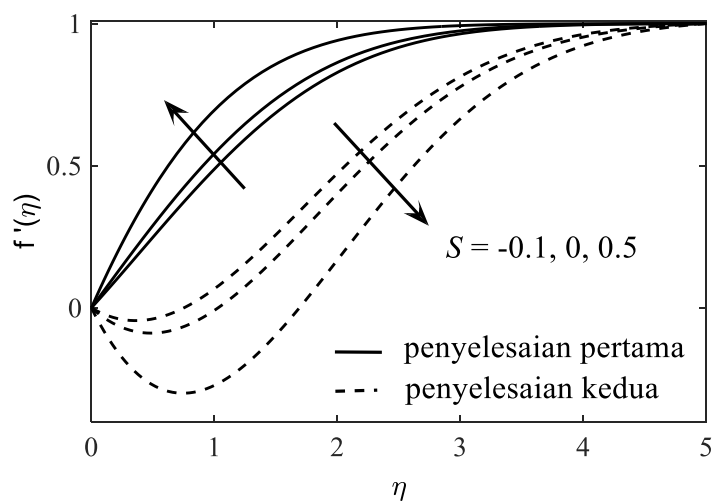

RAJAH 5. Profil halaju $f^{\prime}(\eta)$ bagi beberapa nilai $S$ apabila $\operatorname{Pr}=1$ dan $K=1$ dan $\lambda$ $=-0.8$ (aliran menentang)

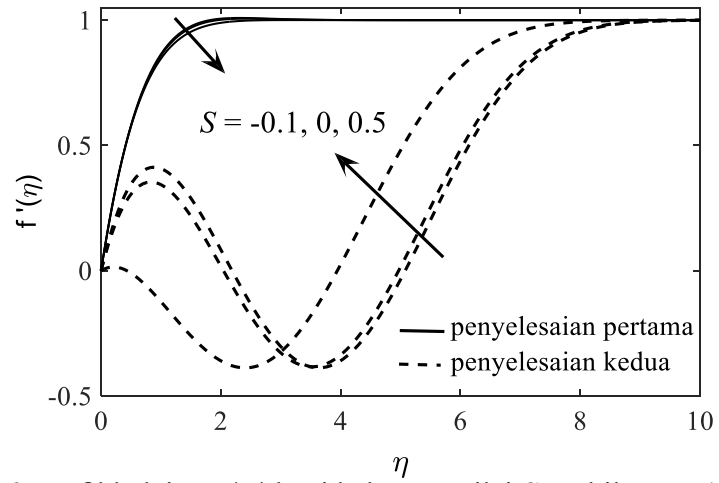

RAJAH 6. Profil halaju $f^{\prime}(\eta)$ bagi beberapa nilai $S$ apabila $\operatorname{Pr}=1$ dan $K=1$ dan $\lambda=1.5$ (aliran membantu) 


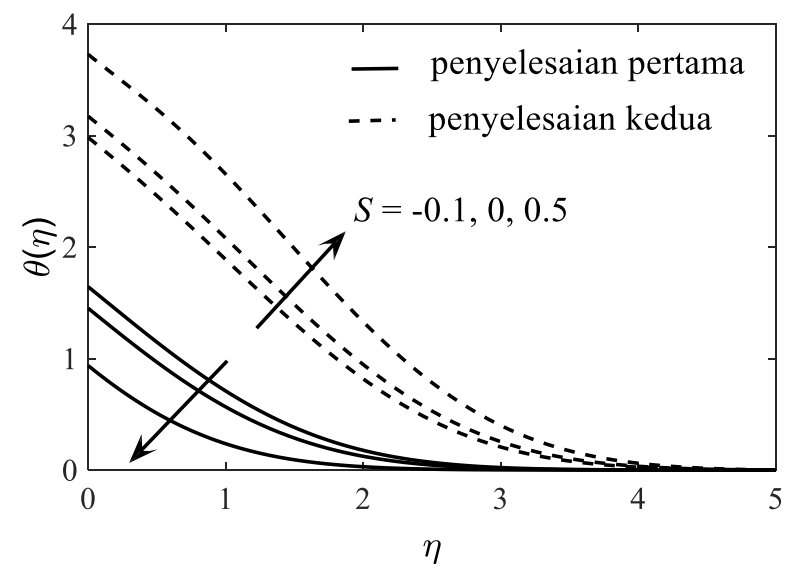

RAJAH 7. Profil suhu $\theta(\eta)$ bagi beberapa nilai $S$ apabila $\operatorname{Pr}=1$ dan $K=1$ dan $\lambda=-0.8$ (aliran menentang)

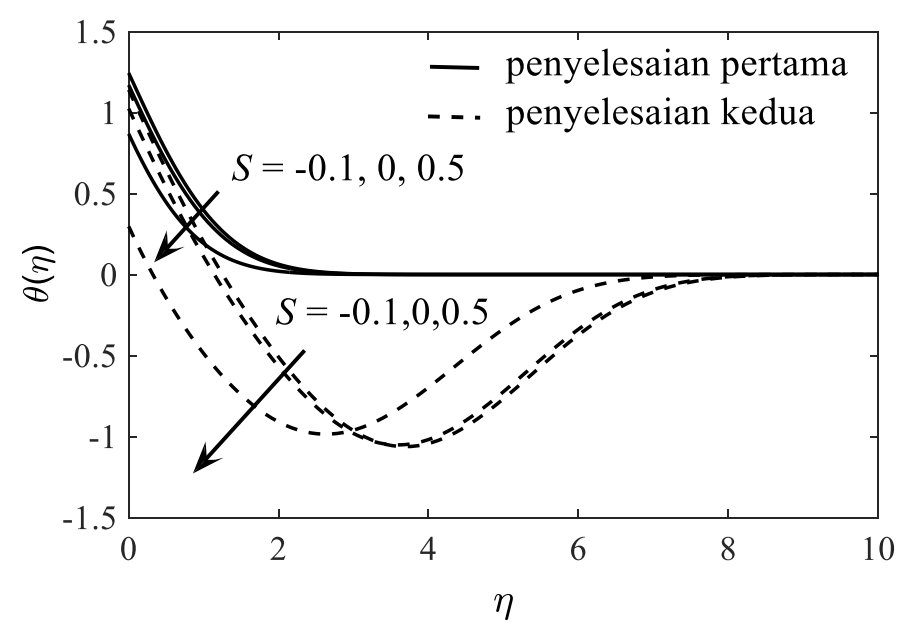

RAJAH 8. Profil suhu $\theta(\eta)$ bagi beberapa nilai $S$ apabila $\operatorname{Pr}=1$ dan $K=1$ dan $\lambda=1.5$ (aliran membantu)

\section{KESIMPULAN}

Masalah aliran genangan dalam bendalir mikrokutub terhadap permukaan mencancang dengan fluks haba permukaan ditetapkan, dengan kesan sedutan/semburan dikaji secara berangka. Daripada kajian ini, didapati pekali geseran kulit dan kadar pemindahan haba pada permukaan meningkat dengan peningkatan parameter sedutan/semburan dan daya keapungan. Penyelesaian dual juga didapati wujud bagi kedua-dua aliran membantu dan aliran menentang. Penyelesaian dual ini wujud sehingga satu nilai kritikal parameter keapungan dalam aliran menentang. Julat penyelesaian dual semakin meningkat dengan pertambahan nilai parameter sedutan/semburan. Analisis kestabilan dilakukan untuk membuktikan bahawa penyelesaian pertama adalah stabil, manakala penyelesaian kedua tidak stabil.

\section{PENGHARGAAN}

Penulis pertama dan kedua ingin merakamkan ucapan terima kasih kepada Kementerian Pelajaran Malaysia di atas bantuan kewangan di bawah Skim Geran Penyelidikan Fundamental (FRGS/1/2018/STG06/UNIMAP/02/3) serta biasiswa MyBrain 15 bagi pembiayaan pengajian $\mathrm{PhD}$ penulis pertama di UniMAP. Sokongan kewangan yang diterima daripada Universiti Kebangsaan Malaysia (Kod Projek: GUP-2018-153) amat dihargai.

\section{RUJUKAN}

Ahmadi, G. 1976. Self-similar solution of incompressible micropolar boundary layer flow over a semi-infinite plate. International Journal of Engineering Science 14: 639-646. Asgharian, A., Domairry Ganji, D., Soleimani, S. \& Asgharian, S. 2010. Analytical solution of stagnation flow of a micropolar 
fluid towards a vertical permeable surface. Thermal Science 14: 383-392.

Awaludin, I.S., Ishak, A. \& Pop, I. 2018. On the stability of MHD boundary layer flow over a stretching/shrinking wedge. Scientific Reports 8: 13622.

Bakar, N.A.A., Bachok, Arifin, N.M. \& Pop, I. 2018. Stability analysis on the flow and heat transfer of nanofluid past a stretching/shrinking cylinder with suction effect. Results in Physics 9: 1335-1344.

Eringen, A.C. 2001. Microcontinuum Field Theories II-Fluent Media. 1st ed. New York: Springer.

Eringen, A.C. 1966. Theory of micropolar fluids. J. Math. Mech. 16: 1-18.

Gorla, R.S.R. 1988. Combined forced and free convection in micropolar boundary layer flow on a vertical flat plate. International Journal of Engineering Science 26: 385-391.

Gupta, D., Kumar, L., Anwar Bég, O. \& Singh, B. 2018. Finite element analysis of MHD flow of micropolar fluid over a shrinking sheet with a convective surface boundary condition. Journal of Engineering Thermophysics 27(2): 202-220.

Hassanien, I. \& Gorla, R.S.R. 1990. Combined forced and free convection in stagnation flows of micropolar fluids over vertical non-isothermal surfaces. International Journal of Engineering Science 28: 783-792.

Ishak, A. 2010. Thermal boundary layer flow over a stretching sheet in a micropolar fluid with radiation effect. Meccanica 45: 367-373.

Ishak, A., Nazar, R., Bachok, N. \& Pop, I. 2010. MHD mixed convection flow near the stagnation-point on a vertical permeable surface. Physica A 389: 40-46.

Jahan, S., Sakidin, H., Nazar, R. \& Pop, I. 2018. Analysis of heat transfer in nanofluid past a convectively heated permeable stretching/shrinking sheet with regression and stability analyses. Results in Physics 10: 395-405.

Jamaludin, A., Nazar, R. \& Pop, I. 2018. Ingham problem for mixed convection flow of a nanofluid over a moving vertical plate with suction and injection effects. Sains Malaysiana 47(9): 2213-2221.

Jamaludin, A., Nazar, R. \& Pop, I. 2017. Stability analysis of flow and heat transfer over a permeable stretching/shrinking sheet with internal heat generation and viscous dissipation. Journal of Physics: Conference Series 890: 012039.

Jusoh, R., Nazar, R. \& Pop, I. 2018. Magnetohydrodynamic rotating flow and heat transfer of ferrofluid due to an exponentially permeable stretching/shrinking sheet. Journal of Magnetism and Magnetic Materials 465: 365-374.

Kamal, F., Zaimi, K., Ishak, A. \& Pop, I. 2019. Stability analysis of MHD stagnation-point flow towards a permeable stretching/shrinking sheet in a nanofluid with chemical reactions effect. Sains Malaysiana 48(1): 243-250.

Kline, K.A. 1977. A spin-vorticity relation for unidirectional plane flows of micropolar fluids. International Journal of Engineering Science 15: 131-134.

Merkin, J.H. 1986. On dual solutions occurring in mixed convection in a porous medium. Journal of Engineering Mathematics 20(2): 171-179.
Mohamed, R.A. \& Abo-Dahab, S.M. 2009. Influence of chemical reaction and thermal radiation on the heat and mass transfer in MHD micropolar flow over a vertical moving porous plate in a porous medium with heat generation. International Journal of Thermal Sciences 48(9): 1800-1813.

Nazar, R., Amin, N., Filip, D. \& Pop, I. 2004. Stagnation point flow of a micropolar fluid towards a stretching sheet. International Journal of Non-Linear Mechanics 39: 12271235.

Ramachandran, N., Chen, T.S. \& Armaly, B.F. 1988. Mixed convection in stagnation flows adjacent to a vertical surfaces. ASME J. Heat Transfer 110: 373-377.

Rosca, A.V. \& Pop, I. 2013. Mixed convection stagnation point flow past a vertical flat plate with a second order slip: Heat flux case. International Journal of Heat and Mass Transfer 65: $102-109$.

Ridha, A. 1996. Aiding flows non-unique similarity solutions of mixed-convection boundary-layer equations. Journal of Applied Mathematics and Physics (ZAMP) 47: 341-352.

Weidman, P.D., Kubitschek, D.G. \& Davis, A.M.J. 2006. The effect of transpiration on self- similar boundary layer flow over moving. International Journal of Engineering Science 44(11-12): 730-737.

Yacob, N.A. \& Ishak, A. 2010. Aliran titik genangan terhadap permukaan meregang dalam bendalir mikropolar dengan fluks haba permukaan boleh ubah. Sains Malaysiana 39(2): 285-290.

Yahaya, R.I., Arifin, N.M. \& Isa, S.S.P.M. 2019. Stability analysis of $M H D$ Carreau fluid flow over a permeable shrinking sheet with thermal radiation. Sains Malaysiana 48(10): 2285-2295.

Zaimi, K. \& Ishak, A. 2012. Aliran genangan bagi bendalir mikrokutub terhadap permukaan mencancang yang telap dengan fluks haba boleh ubah. Sains Malaysiana 41(10): 1263-1270.

Fatinnabila Kamal \& Khairy Zaimi

Institut Matematik Kejuruteraan

Kampus Pauh Putra

Universiti Malaysia Perlis

02600 Arau, Perlis

Malaysia

Anuar Ishak*

Pusat Pengajian Sains Matematik

Fakulti Sains dan Teknologi

Universiti Kebangsaan Malaysia

43600 Bangi, Selangor Darul Ehsan

Malaysia

*Pengarang untuk surat-menyurat: email: anuar_mi@ukm.edu. my

Diserahkan: 18 September 2018

Diterima: 27 Disember 2019 